\title{
Fluxes of Nitrogen, Phosphorus, and Dissolved Organic Carbon in the inflow of the Lehnmühle reservoir (Saxony) as compared to streams draining three main land-use types in the catchment
}

\author{
R. Benning, K. Schua, K. Schwärzel, and K. H. Feger \\ Institute of Soil Science and Site Ecology, Technische Universität Dresden, Tharandt, Germany \\ Correspondence to: R. Benning (raphael.benning@tu-dresden.de)
}

Received: 31 January 2012 - Revised: 20 July 2012 - Accepted: 10 October 2012 - Published: 11 December 2012

\begin{abstract}
The aim of this study was to assess the impact of land-use on inputs of nitrogen, phosphorus, and DOC into the inflow of the Lehnmühle reservoir (drinking water supply). Land-use in the study area is dominated by forest, with smaller proportions of grassland and crops. Water quality was analyzed for the hydrological years 2010 and 2011 at the outlets of three small catchments with homogenous landuse (crops, grassland and forest) and at the outlet of the watershed. The highest nitrogen and phosphorus concentrations were observed in the streams draining the agricultural areas, and the lowest concentrations were found in the forest catchment. The DOC concentration was highest at the outlet of the watershed whereas the concentrations in the small homogeneous catchments were lower. The information collected about the land-use dependent matter exports in these study areas will be used for climate change impact modeling with the Soil and Water Assessment Tool.
\end{abstract}

\section{Introduction}

Water quality at the watershed scale is affected by various sources of biogeochemical fluxes, including pollution from either point or diffuse sources. In watersheds with a high proportion of urban areas, water quality is mainly influenced by point sources such as wastewater treatment plants or local industry. Whereas pollution inputs from rural areas tends to generate from diffuse sources, which will be affected by the specific land-use type (e.g. Wohlrab et al., 1992). The municipal water supply for the German Federal State of Saxony is largely supplied by 22 drinking water reservoirs, which are mostly located in the Ore Mountains with watersheds characterized by rural land use typical of this region.

Monitoring programs to observe water quality are carried out by the State Reservoir Administration of Saxony (LTV). However, their observation points reflect river sections, and as a consequence the analyzed concentrations mostly represent a mixed signal of all land-use types within the upstream river basin (C. P. Reichelt, personal communication, 2009). Therefore, to identify and balance matter inputs related to individual land-use types another approach is needed.

Agricultural land used for the production of crops and grass are known as major source of nitrogen $(\mathrm{N})$ and phosphorus (P) loads in surface waters (Chow et al., 2011). Hence, exports of $\mathrm{N}$ and $\mathrm{P}$ from these areas are potential causes for the eutrophication of water bodies. In contrast to cropped land, the primary negative impact of forests on water quality is through the leaching of dissolved organic carbon (DOC) (e.g. Borken et al., 2011). In the last few decades, increasing DOC concentrations in rivers and lakes have been reported for vast regions in Central and Northern Europe (Hruska et al., 2009; Roulet and Moore, 2006). However, it is unclear what factors have led to this increase in DOC concentration, particularly with respect to the relative contribution of grasslands, forests and wetlands to the increase (Borken et al., 2011).

The objective of this study was to quantify the water quality impacts of the main land-use types of crops, grassland, and forests in a watershed supplying a drinking water reservoir in the low mountain range of the Eastern Ore Mountains. 


\section{Study area}

The area under investigation is the "Lehnmühle watershed" (Fig. 1) which is located in the Eastern Ore Mountains (Saxony, NE Germany, $50^{\circ} 48^{\prime} 18.06^{\prime \prime} \mathrm{N}, 13^{\circ} 36^{\prime} 24.54^{\prime \prime} \mathrm{E}$ ). It covers the uppermost part of the Wilde Weißeritz river watershed with a size of $51 \mathrm{~km}^{2}$, as defined by the streamflow gauging station Ammelsdorf (henceforth referred to as the "Watershed Outlet"; WO). This gauge marks the river's inflow into the Lehnmühle reservoir which is an important drinking water supply for the Dresden metropolitan area. The watershed has a typical low mountain range topography (520-800 ma.s.1.) and silicate bedrock geology with basepoor cambisols and podzols as the major soil types. The catchment area is characterized by a high proportion of forest area ( $\sim 52 \%$, mostly Norway spruce) followed by grassland $(\sim 34 \%)$ and cropland $(\sim 9 \%)$. The annual precipitation is $\sim 1080 \mathrm{~mm}$ (station Hermsdorf, 2005-2011, BfUL, 2011) and the mean annual temperature is $4.9^{\circ} \mathrm{C}$ (station Zinnwald-Georgenfeld, 1971-2010, DWD, 2011).

Within the watershed, three small catchments were selected for each of the main land-use types; "Crops" (near Hermsdorf, with a size of 0.9 ha) (Prasser, 2011), "Grassland" (near Schönfeld, with a size of $17 \mathrm{ha}$ ) and "Forest" (near Rehefeld, with a size of $21 \mathrm{ha}$ ). Within each small study catchment the land use is homogenous, with the intent that they provide a representative sample of these land-use types in the watershed as a whole. The geology of the catchments is characterized by granite porphyry in "Crops", quartz porphyry in "Grassland", and muscovite gneiss in "Forest". Within the "Crops" catchment the granite porphyry underlying the gauging weir is intensely weathered and consists of unconsolidated material. Its permeability causes an unknown quantity of water to flow beneath the site's gauging weir, resulting in an underestimation of streamflow at this site. As a result, the discharge and derived fluxes from this site must be interpreted with care.

\section{Methods}

\subsection{Streamflow recording and sampling}

Continuous streamflow was recorded at the "Watershed Outlet" (Ammelsdorf gauging station) and at the outlets of the three catchments starting in November 2009. At the "Watershed Outlet" data was collected from an existing gauging station, while gauging weirs were installed at the study catchments. At the study catchments, the water level was recorded with ISCO $^{\text {TM }}$ 3220/4220 Submerged Probe Flow Meters, which measure water levels using a pressure sensor. Calculation of discharge at these sites was determined based on the relationship between water level and discharge for each gauging weir. In addition to these discharge measurements, verified discharge data from the local environmental

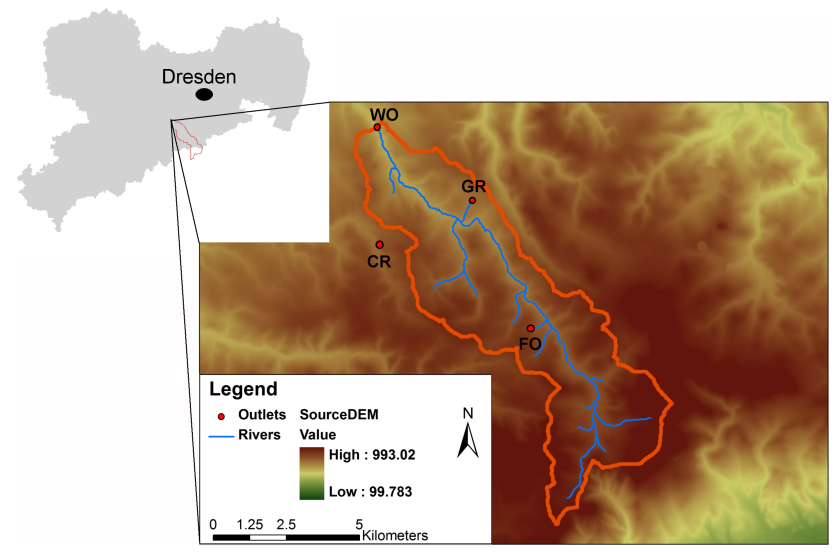

Fig. 1. Lehnmühle watershed with the "Watershed Outlet" (WO) and the catchments "Crops" (CR), "Grassland" (GR), and "Forest" (FO). DEM values are in meters. Source: ATKIS-DGM25 (Germany), S-JTSK (Czech Republic), LfUG (Sächsisches Landesamt für Umwelt und Geologie) (2009b).

authorities (LfULG) for the "Watershed Outlet" was available for the period 1 November 2009 until 31 October 2011 (LfULG, 2012). This data was used for plotting mean daily discharge (cf. Figs. 3 and 4) and calculating matter fluxes at the "Watershed Outlet". Data gaps were filled on a daily time step using a regression equation with discharge from the "Watershed Outlet". Streamflow samples were taken on a weekly basis from the "Watershed Outlet" and the three study catchments, starting in July 2009. In addition to the weekly sampling, event-based water samples were collected using automatic ISCO ${ }^{\mathrm{TM}} 3700$ Portable Samplers, which collect up to 24 individual water samples. Frequency of sampling was controlled by discharge as recorded by the flow meters at each site, which allows the collection of samples at different points in time during a storm event. Collected samples were stored in a cooler box during transportation and kept at $4{ }^{\circ} \mathrm{C}$ until analysis.

\subsection{Water quality analytical methods}

The streamflow samples were analyzed for total phosphorus (TP), according to DIN EN ISO 6878 protocol (DIN, 2004). Immediately after receiving the samples in the laboratory, sulfuric acid was added to the unfiltered samples to prevent changes in TP concentrations. Then, the unfiltered sample was digested with persulfate to convert TP to orthophosphorus (Ortho-P) which was then measured photometrically as molybdenum blue complex (wavelength of $880 \mathrm{~nm}$ ).

A volume of $\sim 250 \mathrm{~mL}$ of each sample was filtered through a $45 \mu \mathrm{m}$-membrane filter. The filtered samples were analyzed for nitrate-nitrogen $\left(\mathrm{NO}_{3}-\mathrm{N}\right)$, ammonium-nitrogen $\left(\mathrm{NH}_{4}-\mathrm{N}\right)$, chloride $\left(\mathrm{Cl}^{-}\right)$using the Segment Flow Analyzer SAN ${ }^{\text {plus }}$ (Skalar Analytics). Ortho-phosphorus (Ortho-P) was analyzed photometrically from the filtered sample according 
to DIN EN ISO 6878 protocol (DIN, 2004). Dissolved organic carbon (DOC) was analyzed using a Heraeus liquid TOC (FOSS). The cations $\mathrm{Na}^{2+}, \mathrm{K}^{+}, \mathrm{Ca}^{2+}, \mathrm{Mg}^{2+}, \mathrm{Al}^{3+}$, $\mathrm{Fe}^{2+}, \mathrm{Mn}^{2+}, \mathrm{Zn}^{2+}$ and the anions $\mathrm{SO}_{4}^{2-}$ and $\mathrm{SiO}_{4}^{4-}$ in the water samples were analyzed as element concentrations by means of ICP (Inductively Coupled Plasma) Spektroscop Spectro (Ciros).

\subsection{Statistical methods}

Basic statistical parameters, time-series, and boxplots were calculated using the $\mathrm{R}$ statistical package, version 2.14.1 (R Development Core Team, 2011). For the boxplots the whiskers cover 1.5 times the interquartile range. All values greater than 1.5 times the interquartile range were defined as outliers, and therefore removed.

\subsection{Calculation of matter fluxes}

Matter fluxes representing export rates from the three catchments and the whole watershed were computed based on the Standard Method, as presented in LAWA (2003). The annual flux $(F)$ was calculated using Eq. (1):

$$
F=\frac{364 \times 86400}{1000 \times 1000} \frac{1}{N} \sum_{i=1}^{N} c\left(t_{i}\right) \times Q\left(t_{i}\right)
$$

where $c\left(t_{i}\right)$ is the measured concentration and $Q\left(t_{i}\right)$ is the daily discharge at a given point in time. Furthermore, the formula contains conversion factors for days per year (364), seconds per day (86400), and for the conversion of the mass unit gram into ton. All fluxes were calculated for the Hydrological Year (HY) which is defined as the period from 1 November until 31 October. The fluxes were calculated for the HY 2010 (1 November 2009 until 31 October 2010) and the HY 2011 (1 November 2010 until 31 October 2011).

\section{Results and discussion}

\subsection{Streamflow}

The mean daily discharge at the outlets of the catchments "Crops", "Grassland", "Forest", and the entire watershed is shown in Fig. 2. The streamflow data contains many peaks, up to a maximum of $422 \mathrm{~L} \mathrm{~s}^{-1} \mathrm{~km}^{-2}$ in the "Grassland" site due to a rapid and intense snowmelt which occurred in January 2011. Therefore, to allow a comparison of streamflow between sites to be interpreted, the scale for the mean daily discharge was limited to $50 \mathrm{~L} \mathrm{~s}^{-1} \mathrm{~km}^{-2}$ and the peaks are not included.

Due to the higher amount of rainfall events during the summer season of HY 2010, the mean daily discharge in HY 2010 was higher than in HY 2011 for all study catchments and the entire watershed. These storm events resulted in particularly high peak flow events in the "Grassland" site, because this catchment is partially underlain with tile drains.

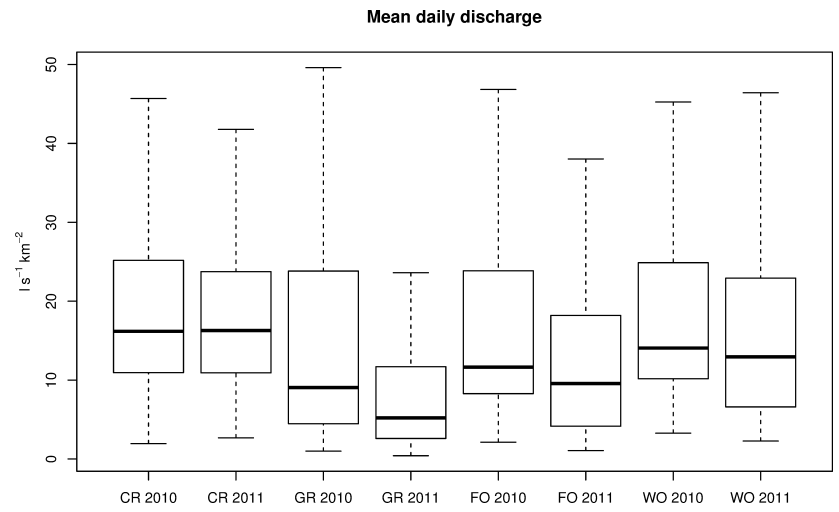

Fig. 2. Box-Whisker plot for the mean daily discharge at the catchments outlets ("Crops" - CR, "Grassland" - GR, and "Forest" FO) and at the "Watershed Outlet" (WO) for hydrological years 2010 and 2011. Whiskers show the lowest value within 1.5 times Interquartile range (IQR) of the lower quartile and highest value within 1.5 times IQR of the upper quartile. Peaks are not shown.

The discharge data for the "Crops" catchment may not provide an accurate representation of the actual discharge rates because of the previously discussed under-estimation of surface flow (cf. Sect. 3.1). The mean daily discharge rates are presented in Figs. 3 and 4.

\subsection{Matter fluxes}

Matter fluxes of nitrogen $\left(\mathrm{NO}_{3}-\mathrm{N}+\mathrm{NH}_{4}-\mathrm{N}\right)$, dissolved phosphorus (Ortho-P), total phosphorus (TP) and dissolved organic carbon (DOC) for the HY 2010 and the HY 2011 are shown in Table 1.

Nitrogen outputs from the catchments vary according to the land-use type. In contrast to the other land-use types, the annual Nitrogen outputs from the "Grassland" catchment varied significantly in HY 2010 and HY 2011. This difference can be attributed to the much higher discharge rate in HY 2010 than in HY 2011. Considering that a part of this site is tile drained it is expected that heavy precipitation events will lead to higher discharge than in a non-tile-drained site.

The mean annual Ortho-P flux was highest in the "Crops" and "Grassland" with $0.11 \mathrm{~kg} \mathrm{ha}^{-1} \mathrm{a}^{-1}$ while in the "Forest" the flux was lowest with $0.01 \mathrm{~kg} \mathrm{ha}^{-1} \mathrm{a}^{-1}$. However, due to the uncertainty due to underground drainage in the "Crops" catchment, the Ortho-P flux at this outlet is maybe underestimated.

Total P fluxes show the same pattern between the different land-use types as for Ortho-P. The highest fluxes were calculated for "Crops", followed by "Grassland" and then "Forest". For "Grassland" and "Forest" the flux levels were in line with data from the official hydro-chemical monitoring published in the "Atlas of nutrient inputs to Saxon water bodies" (LfUG, 2009a) - grassland $\sim 0.16 \mathrm{~kg} \mathrm{ha}^{-1} \mathrm{a}^{-1}$; coniferous forests: $0.04 \mathrm{~kg} \mathrm{ha}^{-1} \mathrm{a}^{-1}$. For cropland the reported annual flux is $\sim 0.38 \mathrm{~kg} \mathrm{ha}^{-1} \mathrm{a}^{-1}$. This is more than the calculated 
Table 1. Catchment export fluxes of nitrogen $\left(\mathrm{NO}_{3}-\mathrm{N}+\mathrm{NH}_{4}-\mathrm{N}\right)$, dissolved phosphorus (Ortho-P), total phosphorus (TP), and dissolved organic carbon (DOC). Fluxes calculated separately for the Hydrological Years (HY) 2010 and 2011 for the catchments "Crops" (CR), "Grassland" (GR), "Forest" (FO), and the "Watershed Outlet” (WO). Calculated numbers in $\mathrm{kg} \mathrm{ha}^{-1} \mathrm{a}^{-1}$.

\begin{tabular}{llrr}
\hline & & HY 2010 & HY 2011 \\
\hline $\mathrm{NO}_{3}-\mathrm{N}+\mathrm{NH}_{4}-\mathrm{N}$ & $\mathrm{CR}$ & 60.4 & 64.0 \\
& GR & 42.6 & 27.4 \\
& FO & 5.4 & 4.0 \\
& WO & 13.9 & 12.6 \\
\hline Ortho-P & CR & 0.10 & 0.12 \\
& GR & 0.13 & 0.08 \\
& FO & 0.01 & 0.01 \\
TP & WO & 0.03 & 0.02 \\
& CR & 0.23 & 0.35 \\
& GR & 0.21 & 0.13 \\
& FO & 0.05 & 0.03 \\
& WO & 0.15 & 0.09 \\
\hline DOC & CR & 4.8 & 4.8 \\
& GR & 18.3 & 9.1 \\
& FO & 9.7 & 5.7 \\
& WO & 26.8 & 18.9 \\
\hline
\end{tabular}

flux of the "Crops" catchment in the present study. This difference may be explained by the fact that the report of LfUG (2009a) does not differentiate between conventional and conservation tillage and that the calculated $P$ export rate represents a mean for the whole of Saxony. Since there is no fertilization with mineral P in the "Crops" catchment of this study, it is reasonable that the annual TP fluxes may be lower there compared to the mean for the whole state territory.

Comparing the DOC fluxes in the three different land-use types, the highest fluxes were observed for "Grassland", followed by "Forest", while the lowest fluxes occurred in the "Crops". It is assumed that the tile draining in the "Grassland" led to higher runoff and a faster input of DOC to the stream. In general, DOC flux is strongly dependent on discharge or water fluxes as Buckingham et al. (2008) have reported. Interestingly, the DOC flux measured at the "Watershed Outlet" was higher than that at any of the individual land-use study sites. This indicates that at the watershed there are additional important sources/contributors for DOC which are not accounted for by the land-use study sites considered.

\subsection{Nitrate}

Nitrate $\left(\mathrm{NO}_{3}-\mathrm{N}\right)$ concentrations were also found to differ between the three different land-use types, as shown in Fig. 3.

As expected, the highest $\mathrm{NO}_{3}-\mathrm{N}$ concentrations were measured in the outlets from catchments under agricultural use ("Crops", "Grassland"). The mean concentration over the

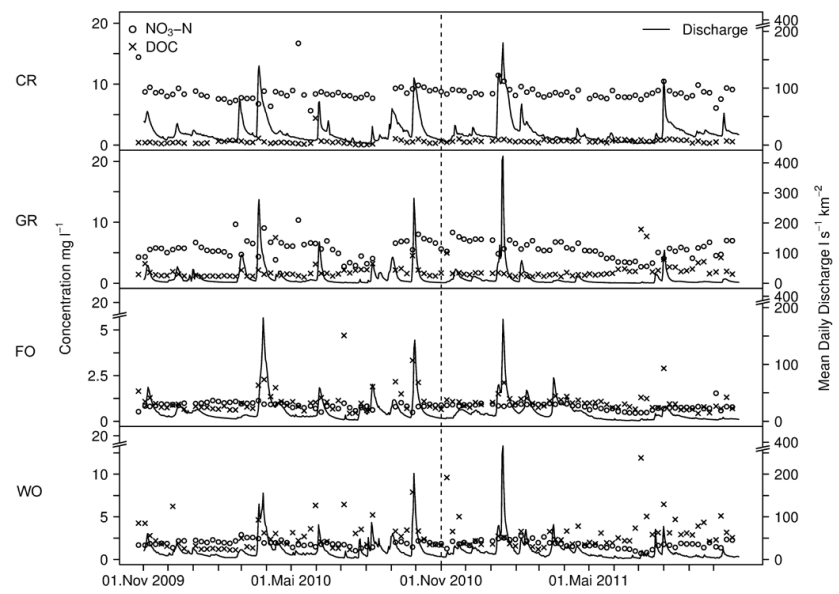

Fig. 3. Time-series of measured concentrations for $\mathrm{NO}_{3}-\mathrm{N}$ and DOC, and mean daily discharge at the catchments representing different land-use types "Crops" (CR), "Grassland" (GR), and "Forest" (FO) and at the "Watershed Outlet" (WO). Scales for concentration and daily discharge vary with the catchments due to different magnitudes. Discharge data for WO was provided by LfULG (2012).

two year sampling period amounted to $8.6 \mathrm{mg} \mathrm{L}^{-1}$ in the streamflow of the "Crops" and $5.6 \mathrm{mg} \mathrm{L}^{-1}$ in the streamflow of the "Grassland". By contrast, the mean concentration in the streamflow of the "Forest" was much lower and amounted to $0.8 \mathrm{mg} \mathrm{L}^{-1}$. The observed seasonal variation in the concentration of $\mathrm{N}$ in the agricultural catchments was low. Higher concentrations were observed at the end of the winter season and after harvesting. Evaluating these catchments based on the water quality classes (WQC) of LAWA (1998), the tributaries with agricultural land-use are classified as WQC III, which indicates a critically high level of nitrate pollution (Schmalz et al., 2008). By contrast, the "Forest" catchment is classified as WQC I, which is defined as "unpolluted" and represents the geological background value. The results of this study match with the findings of Chow et al. (2011), who explored water quality across catchments with a gradient of agricultural intensity in Canada. They found that catchments with high agricultural intensity showed the highest $\mathrm{NO}_{3}-\mathrm{N}$ concentrations $\left(4.39 \mathrm{mg} \mathrm{L}^{-1}\right)$ while primarily forested catchments (i.e. approx. $90 \%$ forest) produced nearly the same low $\mathrm{NO}_{3}-\mathrm{N}$ concentrations as found in the "Forest" site in this study. Similar results were found by Jarvie et al. (2008) with respect to hydro-chemical patterns and to land-use.

The mean $\mathrm{NO}_{3}-\mathrm{N}$ concentration at the "Watershed Outlet" was $\sim 1.8 \mathrm{mg} \mathrm{L}^{-1}$. Hence, the water quality at this section of the river can be classified as WQC II, which is defined as "moderately polluted" (LAWA, 1998; Schmalz et al., 2008). Chow et al. (2011) reported a mean $\mathrm{NO}_{3}-\mathrm{N}$ concentration of $1.24 \mathrm{mg} \mathrm{L}^{-1}$ at the outlet of a watershed with similar landuse distribution as in the present study. Comparing the two 


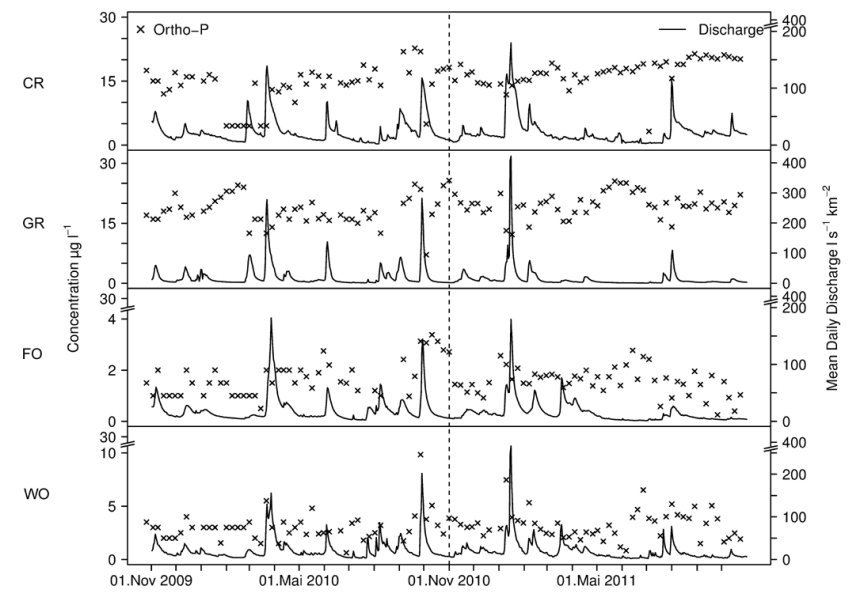

Fig. 4. Time series of measured Ortho-P concentrations and discharge at the catchments representing the different land-use types "Crops" (CR), "Grassland" (GR), and "Forest" (FO) and at the "Watershed Outlet" (WO). Scales for concentration and daily discharge vary with the catchments due to different magnitudes. Discharge data for WO was provided by LfULG (2012).

studies, it can be concluded that at the scale of larger rural watersheds the $\mathrm{NO}_{3}-\mathrm{N}$ concentration is compounded and diluted and thus forms an integrated signal reflecting the landuse distribution within the catchment.

\subsection{Dissolved Organic Carbon}

The time series of DOC concentrations are presented in Fig. 3, which shows a clear difference between the study catchments and the overall watershed. Mean DOC concentrations were highest in the outlet of the "Grassland" $\left(2.0 \mathrm{mg} \mathrm{L}^{-1}\right)$, followed by "Forest" at $1.1 \mathrm{mg} \mathrm{L}^{-1}$, and "Crops" at $0.6 \mathrm{mg} \mathrm{L}^{-1}$. Given the different accumulation of litter which will occur between the different land-use types, the observed gradient in DOC concentration is plausible. The mean DOC concentration observed at the "Watershed Outlet" was significantly higher $\left(2.9 \mathrm{mg} \mathrm{L}^{-1}\right)$ than in the individual catchments, and therefore the DOC concentration at the watershed scale cannot be explained by the types of land-use evaluated in the study catchments. The higher rates of DOC at the "Watershed Outlet" may be due to streamflow originating from peatland/forested areas with organic-rich wet soils located in the uppermost part of the catchment on the German/Czech border. This hypothesis is supported by the fact that the soils within "Forest" are well-drained (terrestrial) soils. This hypothesis will be tested by additional sampling in forthcoming research.

No seasonal variation in DOC concentration was observed in any of the catchments, which instead appeared to be controlled by discharge dynamics. High DOC concentrations correlated with high discharges (resulting from heavy rainfall events) at all observation points, with the exception of "Crops". These results support the findings of Ågren et al. (2010) and Raymond and Saiers (2010), who reported high DOC concentrations during storm events and Hinton et al. (1997) who identified that storm events were responsible for a large portion of annual DOC exports from forested catchments.

\subsection{Ortho-Phosphorus}

The Ortho-P concentrations measured in all study catchments and the "Watershed Outlet" were relatively low, as shown in Fig. 4, and are classified as WQC I (LAWA, 1998). Therefore, the water quality at all observation points is classified as "unpolluted" or "very lightly polluted" with respect to Ortho-P.

Despite the low concentrations of Ortho-P, distinct differences can be identified between the catchments and the entire watershed. While in "Crops" and in "Grassland" the mean Ortho-P concentrations for the two years period were $15.5 \mu \mathrm{gL}^{-1}$ and $18.9 \mu \mathrm{g} \mathrm{L}^{-1}$, the mean Ortho-P concentrations in "Forest" $\left(1.5 \mu \mathrm{g} \mathrm{L}^{-1}\right)$ and the watershed $\left(3.1 \mu \mathrm{g} \mathrm{L}{ }^{-1}\right)$ were $<1 / 5$ of the concentrations in the agricultural areas. These results are in agreement with findings of Jarvie et al. (2008) and Sharpley and Syers (1979). These studies found higher $\mathrm{P}$ loads in fertilized watersheds compared to non-fertilized watersheds, and diffuse sources from agricultural sites were the main contributors of long-term $\mathrm{P}$ loads in basins. Chow et al. (2011) investigated Ortho-P concentration in catchments with varying agricultural activities, and found values ranging from $19.5 \mu \mathrm{g} \mathrm{L}^{-1}$ (low agricultural intensity) to $56.4 \mu \mathrm{g} \mathrm{L}^{-1}$ (high agricultural intensity). The observed Ortho-P concentrations in the present study are significantly lower than the values of Chow et al. (2011). That might be attributed to conservation tillage without ploughing, since the farming company shifted soil preparation from traditional tillage to conservation tillage in 1999. With this change in management also the fertilization with mineral phosphorus was stopped. In the "Grassland" site, liquid manure from dairy production was continuously applied and is a considerable source for $\mathrm{P}$. The Ortho-P values seen in this site are unexpected low. Bechmann et al. (2005) also reported lower Ortho-P concentrations in streams from agricultural areas used for dairy production compared to areas with cereal production, which also supports the findings of Chow et al. (2011) that streams from areas with intensive crop production show higher Ortho-P concentrations.

As Ortho-P is a rapidly available form of the macronutrient $\mathrm{P}$, a distinct seasonal variation in concentrations can be identified in all catchments (Fig. 4). During the growing season, Ortho-P concentrations are lower than in the dormant season, and this pattern is particularly clear in the "Grassland" site. In contrast, there is no obvious seasonal variation at the "Watershed Outlet", and the variation in Ortho$\mathrm{P}$ concentration there may be attributable to heavier rainfall events causing peak flow events in the stream. Again, this is in contrast to the concentrations in the catchments which 
were measured simultaneously. Hence, the higher Ortho-P inputs during heavy rainfall events may result from peatland areas within the upper part of the watershed. Another explanation may be Ortho-P mobilization from settlements under high flow conditions.

\section{Conclusions}

The results of this study indicate that the export of N, P, and DOC depends on the type of land-use. The highest export rates of $\mathrm{N}$ and $\mathrm{P}$ occured under agricultural sites, and the lowest were from the "Forest" site. While the $\mathrm{N}$ exports are generated from diffuse sources, the $\mathrm{P}$ export pattern varied depending on the scale considered. On the plot scale (catchments "Crops" and "Grassland") the export is generated from diffuse sources; while point sources appear to control P exports at the watershed scale. Given the discrepancy between DOC concentrations at the catchment and watershed scale, DOC contributions to streamflow clearly originated from diffuse sources. One important task of future research in this watershed is the identification of these diffuse sources of high DOC concentrations.

With regard to water quality at the watershed scale, improvements will depend upon future land-use allocation and management strategies. Based on the findings of this study, two strategies which may improve water quality are the adoption of conservation tillage methods and afforestation within the watershed. Both would reduce the risk of soil erosion and lowers the sediment and matter entry into the river.

Acknowledgements. This study was conducted within the frame of REGKLAM (Development and Testing of an Integrated Regional Climate Change Adaptation Programme for the Model Region of Dresden), project no. 01LR0802B financed by the German Federal Ministry for Education and Research (BMBF). The authors thank Ruth Rüger, Ina Klemm, Claudia Thiere, and Thomas Klinger for the laboratory analysis and Norbert Prange for his support during the field campaigns. Special thanks go to Daniel Hawtree for the language editing of the manuscript. The authors also thank the two reviewers for the useful comments and the editors.

Edited by: K. Schneider and S. Achleitner

Reviewed by: K. Drastig and one anonymous referee

\section{References}

Ågren, A., Haei, M., Köhler, S. J., Bishop, K., and Laudon, H.: Regulation of stream water dissolved organic carbon (DOC) concentrations during snowmelt; the role of discharge, winter climate and memory effects, Biogeosciences, 7, 2901-2913, doi:10.5194/bg-7-2901-2010, 2010.

Bechmann, M. E., Berge, D., Eggestad, H. O., and Vandsemb, S. M.: Phosphorus transfer from agricultural areas and its impact on the eutrophication of lakes - two long-term integrated studies from Norway, J. Hydrol., 304, 238-250, 2005.
BfUL (Betriebsgesellschaft für Umwelt und Landwirtschaft): Precipiation data of the station Hermsdorf/Erzgebirge 2005-2011, 2011.

Borken, W., Ahrens, B., Schulz, C., and Zimmermann, L.: Site-tosite variability and temporal trends of DOC concentrations and fluxes in temperate forest soils, Glob. Change Biol., 17, 24282442, 2011.

Buckingham, S., Tipping, E., and Hamilton-Taylor, J.: Concentrations and fluxes of dissolved organic carbon in UK topsoils, Sci. Total Environ., 407, 460-470, 2008.

Chow, L., Xing, Z., Benoy, G., Rees, H. W., Meng, F., Jiang, Y., and Daigle, J. L.: Hydrology and water quality across gradients of agricultural intensity in the Little River watershed area, New Brunswick, Canada, J. Soil Water Conserv., 66, 71-84, 2011.

DIN (Deutsches Institut für Normung e.V.): DIN EN ISO 6878, Wasserbeschaffenheit - Bestimmung von Phosphor - Photometrisches Verfahren mittels Ammoniummolybdat, 2004.

DWD (Deutscher Wetterdienst): Climate data of the station Zinnwald-Georgenfeld 1971-2010, 2011.

Hinton, M. J., Schiff, S. L., and English, M. C.: The significance of storms for the concentration and export of dissolved organic carbon from two Precambrian Shield catchments, Biogeochemistry, 36, 67-88, 1997.

Hruska, J., Kram, P., McDowell, W. H., and Oulehle, F: Increased dissolved organic carbon (DOC) in central European streams is driven by reductions in ionic strength rather than climate change or decreasing acidity, Environ. Sci. Technol., 43, 4320-4326, 2009.

Jarvie, H. P., Withers, P. J. A., Hodgkinson, R., Bates, A., Neal, M., and Wickham, H. D.: Influence of rural land use on streamwater nutrients and their ecological significance, J. Hydrol., 350, 166186, 2008.

LAWA (Länderarbeitsgemeinschaft Wasser): Beurteilung der Wasserbeschaffenheit von Fließgewässern in der Bundesrepublik Deutschland - Chemische Gewässergüteklassifikation, Kulturbuchverlag Berlin, 1998.

LAWA (Länderarbeitsgemeinschaft Wasser): Ermittlung von StoffFrachten in Fließgewässern Probenahmestrategien und Berechnungsverfahren, Kulturbuchverlag Berlin, 10-12, 2003.

LfUG (Sächsisches Landesamt für Umwelt und Geologie): Atlas der Nährstoffeinträge in sächsische Gewässer, 80 pp., 2009a.

LfUG (Sächsisches Landesamt für Umwelt und Geologie): Digitales Geländemodell ATKIS-DGM25 (Germany) und S-JTSK (Czech Republic), 2009b.

LfULG (Sächsisches Landesamt für Umwelt, Landwirtschaft und Geologie): Proved discharge data for the Ammelsdorf gauge (Watershed Outlet) for the Hydrological Year 2010 and 2011, 2012.

Prasser, M: Modellierung hydrologischer Prozesse im Experimentaleinzugsgebiet Acker mit WaSiM-ETH. HydrologischMeteorologische Projektarbeit, Technische Universität Dresden, Institut für Hydrologie und Meteorologie, Dresden, 2011.

R Development Core Team: R: A language and environment for statistical computing, R Foundation for Statistical Computing, Vienna, Austria, 2011.

Raymond, P. A. and Saiers, J. E.: Event controlled DOC export from forested watersheds, Biogeochemistry, 100, 197-209, 2010.

Roulet, N. and Moore, T. R.: Browning the waters, Nature, 444, 283-284, 2006. 
Schmalz, B., Bieger, K., and Fohrer, N.: A method to assess instream water quality - the role of nitrogen entries in a North German rural lowland catchment, Adv. Geosci., 18, 37-41, doi:10.5194/adgeo-18-37-2008, 2008.

Sharpley, A. N. and Syers, J. K.: Phosphorus inputs into a stream draining an agricultural watershed, Water Air Soil Poll., 11, 417$428,1979$.
Wohlrab, B., Ernstberger, H., Meuser, A., and Sokollek, V.: Landschaftswasserhaushalt: Wasserkreislauf und Gewässer im ländlichen Raum; Veränderungen durch Bodennutzung, Wasserbau und Kulturtechnik.-Paul Parey, Hamburg, 352 pp., 1992. 